\title{
Biomass and Carbon in a Seasonal Semideciduous Forest in Minas Gerais
}

\author{
Helane França Silva ${ }^{1}$, Sabina Cerruto Ribeiro ${ }^{2}$, Soraya Alvarenga Botelho ${ }^{3}$, \\ Gilberto Rodrigues Liska ${ }^{4}$, Marcelo Angelo Cirillo ${ }^{4}$ \\ ${ }^{1}$ Departamento de Engenharia Florestal, Universidade Federal do Piauí - UFPI, Campus Professora Cinobelina Elvas, Bom \\ Jesus/PI, Brasil \\ ${ }^{2}$ Departamento de Engenharia Florestal, Centro de Ciências Biológicas e da Natureza, Universidade Federal do Acre - \\ UFAC, Rio Branco/AC, Brasil \\ ${ }^{3}$ Departamento de Ciências Florestais, Universidade Federal de Lavras - UFLA, Lavras/MG, Brasil \\ ${ }^{4}$ Departamento de Ciências Exatas, Universidade Federal de Lavras - UFLA, Lavras/MG, Brasil
}

\begin{abstract}
The objective of the present study was to quantify the biomass and carbon stock in a Seasonal Semideciduous Forest remnant in southern Minas Gerais. Forest inventory data taken between 2010 and 2013 in permanent plots, was used to estimate biomass with an allometric equation. Basic wood density $(\mathrm{Db})$ and carbon content were determined in the laboratory and the carbon stock was obtained by multiplying biomass by carbon content. The species with the lowest and highest $\mathrm{Db}$ were Nectandra lanceolata $\left(0.38 \mathrm{~g} \mathrm{~cm}^{-3}\right)$ and Machaerium villosum $\left(0.77 \mathrm{~g} \mathrm{~cm}^{-3}\right)$. The species that showed the lowest and highest carbon content values were Casearia decandra (41.85\%) and Nectandra oppositifolia (46.57\%). The biomass stock for the area was $126.92 \pm 0.09 \mathrm{t} \mathrm{ha}^{-1}$, which corresponded to $55.91 \pm 0.05 \mathrm{t} \mathrm{ha}^{-1}$ of carbon stock and a periodic annual increment of $3.07 \mathrm{t} \mathrm{ha}^{-1}$ year $^{-1}$.
\end{abstract}

Keywords: carbon content, carbon stock, carbon increment, natural forests. 


\section{INTRODUCTION}

Natural forest conservation is a strategy to mitigate global climate change (Sharma et al., 2013), as it increases the carbon stored in forest biomass and reduces the emission of greenhouse gases (GHG) into the atmosphere, which occurs either through deforestation or forest degradation (Lung \& Espira, 2015). However, to assess the real contribution of forests to the removal of atmospheric carbon and the magnitude of GHG emissions in the case of deforestation, it is essential to quantify aboveground forest biomass and carbon stock (Gibbs et al., 2007).

In forest ecosystems, woody biomass and its carbon content determine the amount of carbon stored by vegetation (Conti \& Díaz, 2013). Nonetheless, in natural forests there is great variation in the capacity of each species to accumulate biomass and store carbon, mainly due to the great diversity of species and the high variability between individuals of the same species (Baker et al., 2004). Therefore, biomass should be carefully evaluated in these forests, because stored carbon will be quantified based on this value (Brown, 1997).

Biomass in natural forests is commonly obtained via indirect methods, mainly using allometric equations, because obtaining biomass directly from felled trees (direct method) is difficult due to technical and legal issues. In general, the few published studies using the direct method are based on a small number of harvested individuals. Moreover, harvesting large trees is rare, therefore most of the equations generated from the direct method are not representative of the whole forest (Parresol, 1999; Chave et al., 2005).

The carbon stock is obtained by multiplying the biomass by the carbon content. Many studies have used the factor 0.5 proposed by the Intergovernmental Panel on Climate Change to make the conversion of biomass into carbon stock (Soares \& Oliveira, 2002; IPCC, 2003; Houghton, 2005; Ribeiro et al., 2009; Almeida et al., 2010; Paiva et al., 2011; Souza \& Fiorentin, 2013). However, the use of a generic value for carbon content can lead to erroneous estimates of the carbon stock, due to the great diversity of species and climatic and topographic conditions to which natural forests are subject.
Therefore, determining the carbon content by species is essential to obtain more accurate estimates of the carbon sequestration capacity of natural forests. Similarly, it is also important to obtain other key variables to determine forest biomass, such as basal area and basic wood density (Chave et al., 2005; Henry et al., 2010). These variables can support studies aiming to develop allometric equations to estimate forest biomass, since they increase the specificity of the biomass estimates by including intrinsic species data.

Several studies have sought to estimate carbon stock for different Brazilian forest typologies, with significant emphasis on the Amazon region (Souza et al., 2012a; Silva et al., 2014, 2015; Nogueira et al., 2015). However, little is known about the Atlantic Forest biome capacity to store carbon. In this biome, the physiognomy with the largest original distribution is the Seasonal Semideciduous Forest. It presents great floristic diversity and has been a constant target of deforestation, with only around $4 \%$ of its original forest cover remaining (Brasil, 2007). Despite its ecological importance, few studies have attempted to quantify the carbon stock in this physiognomy (Scolforo et al., 2008a; Ribeiro et al., 2009; Souza et al., 2012b; Amaro et al., 2013; Torres et al., 2013; Carvalho et al., 2014; Gaspar et al., 2014; Figueiredo et al., 2015).

Therefore, this study aimed to quantify the biomass and carbon stock in a Seasonal Semideciduous Forest remnant in southern Minas Gerais.

\section{MATERIAL AND METHODS}

\subsection{Study area}

This study was conducted in a forest remnant belonging to Companhia Energética de Minas Gerais - CEMIG, located upstream from the Camargos reservoir, on the right bank of Grande River, in Itutinga, Minas Gerais (Figure 1). The forest remnant has 1.2 hectares $\left(21^{\circ} 19^{\prime} 25^{\prime \prime} \mathrm{S}, 44^{\circ} 36^{\prime} 50^{\prime \prime} \mathrm{W}\right)$ and covers a riparian area of Seasonal Semideciduous Forest with no record of recent anthropogenic intervention.

The natural vegetation of the study area is constituted by different forest formations, with a predominance of the seasonal semideciduous forest physiognomy (Scolforo et al., 2008b). The climate of the region is a transition between Cwa and Cwb, according to Köppen's 


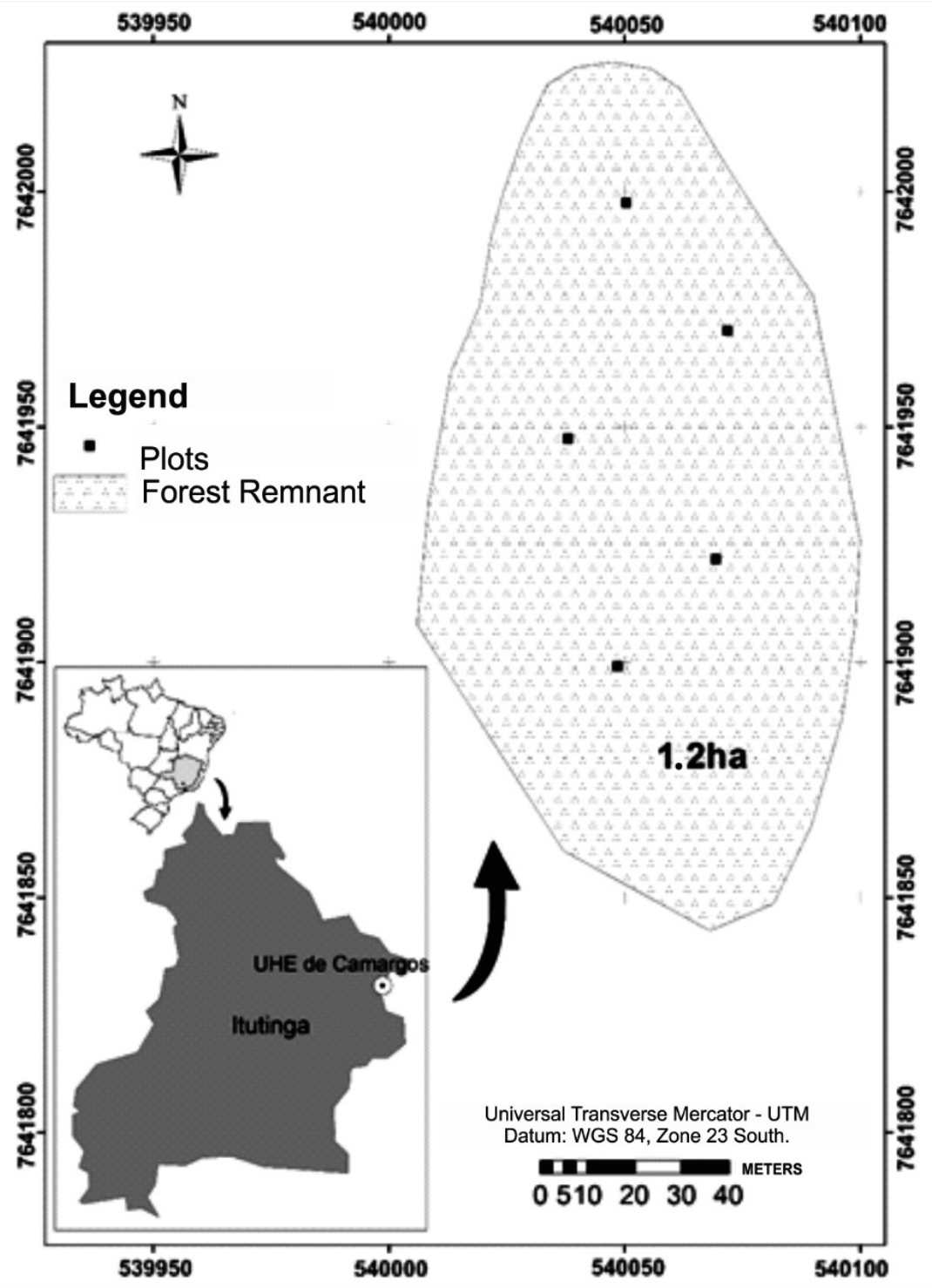

Figure 1. Forest remnant area around the Camargos reservoir, Itutinga, MG.

climate classification (Antunes, 1986). The average local altitude is $900 \mathrm{~m}$; the average annual rainfall and temperature are $19.4^{\circ} \mathrm{C}$ and $1529.7 \mathrm{~mm}$, respectively, with a dry period from April to September. The dominant soil type in the study area is the Red Latosol.

\subsection{Determination of biomass, basic wood density and carbon content}

In 2010, a first forest inventory was conducted in five permanent plots of $20 \mathrm{~m} \times 20 \mathrm{~m}$ established in the forest remnant. In each plot, all trees with a circumference at $1.30 \mathrm{~m}$ from the ground $(\mathrm{CBH}) \geq 15 \mathrm{~cm}$ were recorded, identified botanically and had their total height and $\mathrm{CBH}$ measured. Trees with multiple stems had all the stems measured and the equivalent diameter calculated (Soares et al., 2011). In July 2013, a second forest inventory was conducted using the same criteria adopted in 2010. Subsequently, the parameters related to the horizontal structure (density, dominance, frequency and importance value) were estimated, according to Moro \& Martins (2011).

Dry woody biomass of the tree stratum (DB) was estimated using Equation 1 (Scolforo et al., 2008c): 
$\ln (\mathrm{DB})=-10.9532786932+2.5464820134 \times$

$\ln (\mathrm{DBH})+0.4667754371 \times \ln (H)$

$\left(\bar{R}^{2}=95.71 ; \mathrm{S}_{y x}=41.74 \%\right)$

in which: $\mathrm{DB}=$ dry biomass $\left(\mathrm{t} \mathrm{ha}^{-1}\right) ; \mathrm{DBH}=$ diameter at $1.30 \mathrm{~m}$ from the ground $(\mathrm{cm}) ; \mathrm{H}=$ total height $(\mathrm{m})$.

The horizontal structure (Value of Importance VI and basal area) was used to determine the basic wood density and carbon content. Twenty species (about $40 \%$ of the total) of high ecological importance that contribute $87 \%$ of the total basal area of the site, were selected. The minimum number of trees sampled per species was proportional to the value of the relative density obtained from the forest inventory (Scolforo \& Thiersch, 2004). The diameter distribution of the trees recorded in the forest inventory was used to select which individuals would be sampled, totaling 50 trees (15\% of the total).

In the selected individuals, a $5 \mathrm{~mm}$ diameter bark sample (baguettes) was collected $1.30 \mathrm{~m}$ from the ground using an increment borer. The instrument was introduced into the trunk of the standing tree to a depth equal to half the diameter. The samples were then stored in plastic bags with water, which were kept in a Styrofoam box to avoid samples being damaged and moisture loss. Each bag was previously marked with the sample number and place and date of collection. After removing the sample, the lesion was sprinkled with Bordeaux syrup to prevent possible contamination of the tree by pathogens. Finally, a piece of wood was inserted into the hole made in the stem.

Basic wood density (WD, Equation 2) was determined in the laboratory for the bored species, by the ratio between dry biomass (DB) and its saturated volume (SV), which was obtained based on Archimedes' Principle. The basic wood density of each species was calculated by the arithmetic mean of the sample densities of the same species.

$$
W D=\frac{\text { Dry biomass }(D B)}{\text { Saturated volume }(S V)}
$$

in which: WD = basic wood density $\left(\mathrm{g} \mathrm{cm}^{-3}\right) ; \mathrm{DB}=$ dry biomass $(\mathrm{g}) ; \mathrm{SV}=$ saturated volume $\left(\mathrm{cm}^{3}\right)$.

Wood samples were then packed in paper bags and oven dried at $103 \pm 2{ }^{\circ} \mathrm{C}$ until their dry weight was stabilized. After weighing, the oven dried material was ground, macerated using a pestle, sieved in 60-mesh sieve and the powder retained therein was properly stored and sent for carbon content analysis.
Carbon content was determined using subsamples ( 3 to $5 \mathrm{mg}$ ) packed in tin capsules, which were injected in a furnace at $950{ }^{\circ} \mathrm{C}$ for dry combustion in a Vario TOC Cube analyzer. The $\mathrm{CO}_{2}$ gas emitted by each sample was quantified by an NDIR infrared detector and the carbon generated was related to the evaluated sample mass (mg). The carbon content of each sampled species was calculated by the arithmetic mean of the carbon content of the samples from the same species. For the species for which this information was not available, an average value obtained from the species sampled was used.

\subsection{Estimation of carbon stock and increment}

Total carbon stock was estimated multiplying the estimated biomass (DB; Equation 1) by the respective sample carbon content obtained in the laboratory. The carbon stock values obtained were extrapolated to the hectare.

Periodic annual carbon stock increment (PAIc) in the study area was also calculated for the periods of 2010 and 2013 (Equation 3).

PAIc $=\frac{C_{2013}-C_{2010}}{n}$

in which: PAIc $=$ periodic annual increment of the carbon stock $\left(\mathrm{t} \mathrm{ha}^{-1}\right) ; \mathrm{C}_{2013}=\operatorname{carbon}$ stock $\left(\mathrm{t} \mathrm{ha}^{-1}\right)$ in 2013; $\mathrm{C}_{2010}=$ carbon stock $\left(\mathrm{t} \mathrm{ha}^{-1}\right)$ in $2010 ; \mathrm{n}=$ measurement interval, in this case, 3 years.

PAIc in 2010 and 2013 were obtained according to Equation 4 (Scolforo et al., 2008d), since the carbon stock estimation obtained in 2010 was calculated using this equation (Faria, 2012).

$$
\begin{aligned}
& \ln (C)=-12.3034390630+2.6584231780 \times \\
& \ln (\mathrm{DBH})+0.5711719721 \times \ln (H) \\
& \left(\bar{R}^{2}=97.25 ; \mathrm{S}_{\mathrm{yx}}=36.40 \%\right)
\end{aligned}
$$

in which: $\mathrm{C}=$ carbon stock $\left(\mathrm{t} \mathrm{ha}^{-1}\right) ; \mathrm{DBH}=$ diameter at $1.30 \mathrm{~m}$ from the ground $(\mathrm{cm}) ; \mathrm{H}=$ total height $(\mathrm{m})$.

\section{RESULTS AND DISCUSSION}

\subsection{Characterization of the arboreal stratum}

Based on the forest inventory in the Seasonal Semideciduous Forest remnant, 50 tree species were counted, belonging to 26 botanical families. The families 
with the highest number of species in the survey were Fabaceae (10), Lauraceae (6) and Myrtaceae (4). Copaifera langsdorffii (Fabaceae Caesalpinioideae) and Tapirira obtusa (Anacardiaceae) presented the highest importance values in the study area (Table 1 ). Oliveira \& Ratter (2000) highlight that these species commonly occur in riparian areas and are considered generalists with a wide distribution.

The average density of individuals per hectare was 1,790 and the mean $\mathrm{DBH}$ and basal area values were $12.95 \mathrm{~cm}$ and $31.85 \mathrm{~m}^{2} \mathrm{ha}^{-1}$, respectively. Other studies carried out on Seasonal Semideciduous Forest fragments (DAP $\geq 5 \mathrm{~cm}$ ) in Minas Gerais found a basal area ranging from 22.92 to $31.03 \mathrm{~m}^{2} \mathrm{ha}^{-1}$ and density ranging from 322 to 1500 ind ha $^{-1}$ (Vilela et al., 2000; Espírito-Santo et al., 2002; Souza et al., 2003; Scolforo et al., 2008e). Therefore, it seems that there is no uniformity between tree communities, which indicates that the Seasonal Semideciduous Forest fragments of the region can present striking structural differences (Souza et al., 2003).
The diametric distribution presented an inverted J-shaped curve, or negative exponential curve (Figure 2), in which $56 \%$ of individuals occur in the first class $(5-10 \mathrm{~cm})$. This distribution is characteristic of natural forests, where the frequency of individuals tends to decline with increasing diameter (Souza et al., 2012c; Lima \& Leão, 2013; Calixto \& Drumond, 2014).

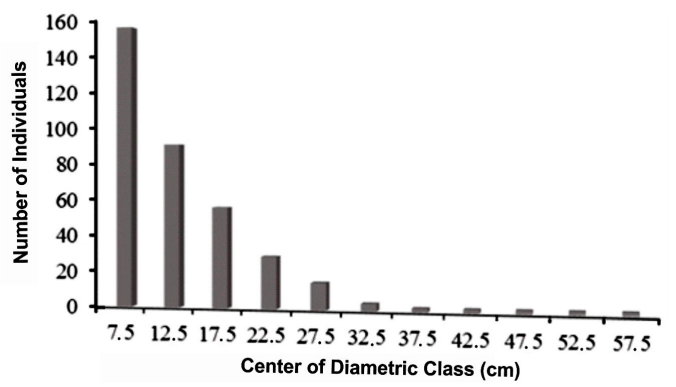

Figure 2. Diametric distribution of individuals sampled in the forest remnant area around the Camargos reservoir, Itutinga, MG.

Table 1. Phytosociological parameters and ecological group of the twenty species with the highest Importance Value in a forest remnant around the Camargos reservoir, Itutinga, MG.

\begin{tabular}{|c|c|c|c|c|c|c|}
\hline Species & $\mathbf{N}$ & RD & RDo & RF & IV & G \\
\hline Copaifera langsdorffii Desf. & 102 & 28.49 & 34.06 & 0.05 & 62.60 & 2.17 \\
\hline Tapirira obtusa (Benth.) J.D.Mitch. & 41 & 11.45 & 12.86 & 0.05 & 24.35 & 0.82 \\
\hline Cryptocarya aschersoniana Mez. & 24 & 6.70 & 7.91 & 0.04 & 14.65 & 0.50 \\
\hline Protium heptaphyllum (Aubl.) Marchand & 31 & 8.66 & 5.10 & 0.05 & 13.81 & 0.32 \\
\hline Peltophorum dubium (Spreng.) Taub. & 8 & 2.24 & 3.21 & 0.04 & 5.48 & 0.20 \\
\hline Dalbergia nigra (Vell.) Allemão ex Benth. & 8 & 2.24 & 2.51 & 0.04 & 4.78 & 0.16 \\
\hline Persea willdenowii Kosterm. & 1 & 0.28 & 4.15 & 0.01 & 4.43 & 0.26 \\
\hline Lithraea molleoides (Vell.) Engl. & 4 & 1.12 & 3.20 & 0.01 & 4.32 & 0.20 \\
\hline Nectandra lanceolata Nees & 6 & 1.68 & 2.26 & 0.03 & 3.96 & 0.14 \\
\hline Nectandra oppositifolia Nees & 6 & 1.68 & 1.91 & 0.02 & 3.60 & 0.12 \\
\hline Vismia brasiliensis Choisy & 10 & 2.79 & 0.68 & 0.04 & 3.51 & 0.04 \\
\hline Protium warmingianum Marchand & 8 & 2.24 & 1.23 & 0.05 & 3.51 & 0.08 \\
\hline Nectandra nitidula Nees & 6 & 1.68 & 1.73 & 0.03 & 3.43 & 0.11 \\
\hline Casearia sylvestris $\mathrm{Sw}$. & 8 & 2.24 & 0.50 & 0.03 & 2.76 & 0.03 \\
\hline Guarea guidonia (L.) Sleumer & 6 & 1.68 & 0.72 & 0.03 & 2.43 & 0.05 \\
\hline Casearia decandra Jacq. & 7 & 1.96 & 0.29 & 0.03 & 2.28 & 0.02 \\
\hline Ormosia arborea (Vell.) Harms & 4 & 1.12 & 1.11 & 0.02 & 2.25 & 0.07 \\
\hline Machaerium villosum Vogel & 1 & 0.28 & 1.76 & 0.01 & 2.04 & 0.11 \\
\hline Myrcia venulosa DC. & 5 & 1.40 & 0.56 & 0.02 & 1.97 & 0.04 \\
\hline Guazuma crinita Mart. & 2 & 0.56 & 1.33 & 0.01 & 1.90 & 0.08 \\
\hline
\end{tabular}

Note: $\mathrm{N}$ = number of individuals; $\mathrm{RD}=$ relative density (\%); RDo = relative dominance (\%); $\mathrm{RF}=$ relative frequency $(\%)$; $\mathrm{IV}=$ importance value $(\%) ; \mathrm{G}=$ basal area $\left(\mathrm{m}^{2}\right)$. 


\subsection{Biomass, basic wood density and carbon content}

Total biomass in the evaluated forest remnant was $126.92 \pm 0.09 \mathrm{t} \mathrm{ha}^{-1}$, corresponding to a carbon stock of $55.91 \pm 0.05 \mathrm{t} \mathrm{ha}^{-1}$. Basic wood density (Table 2) ranged from $0.38 \mathrm{~g} \mathrm{~cm}^{-3}$ (Nectandra lanceolata Nees) to $0.77 \mathrm{~g} \mathrm{~cm}^{-3}$ (Machaerium villosum Vogel). Basic wood density (WD) can vary between genera, between species of the same genus and between trees of the same species, besides variation due to edaphoclimatic factors (Latorraca \& Albuquerque, 2000). This variation makes WD an important variable to be included in carbon stock prediction models, since it reflects environmental conditions (Chave et al., 2005; Williamson \& Wiemann, 2010). Carbon content showed a variation between $41.85 \%$ (Casearia decandra Jacq) and $46.57 \%$ (Nectandra oppositifolia Nees). In a study conducted by Watzlawick et al. (2011) in a Mixed Ombrophilous Forest fragment, large stem carbon content variations were also found between species (39.45\% to $44.12 \%)$. This highlights the importance of determining the carbon content for each species, regardless of the physiognomy to which it belongs. These determinations allow a more reliable estimation of the carbon stored in the forest biomass.

\subsection{Carbon stock increment in 2010 and 2013}

In this study, the periodic annual carbon stock increment (PAIc) was evaluated for all the species found in the remnant. The five species with the highest IPA ${ }_{C}$ were: Copaifera langsdorffii (7.75 tha $\left.\mathrm{t}^{-1} \mathrm{year}^{-1}\right)$, Tapirira obtusa (1.29 $\mathrm{t} \mathrm{ha}^{-1}$ year $\left.^{-1}\right)$, Dalbergia nigra (1.22 $\mathrm{t} \mathrm{ha}^{-1}$ year $\left.^{-1}\right)$, Cryptocarya aschersoniana (1.21 tha $\left.\mathrm{t} \mathrm{year}^{-1}\right)$ and Persea willdenowii $\left(1.03 \mathrm{t} \mathrm{ha}^{-1}\right.$ year $\left.^{-1}\right)$. These species are among the ten most ecologically important species (Table 1) and made the greatest contribution to the IPA ${ }_{C}$ of the evaluated forest remnant.

Using the carbon stock increments in the period between 2010 and 2013, we obtained an IPA of $_{\text {, }}$ 3.07 tha $^{-1}$ year ${ }^{-1}$, considering all the species present in the remnant. Souza et al. (2011) evaluated the stock and growth in volume, biomass, carbon and carbon

Table 2. Mean values of basic wood density and carbon content of the twenty species sampled in a forest remnant around the Camargos reservoir, Itutinga, MG.

\begin{tabular}{|c|c|c|}
\hline Species & $\begin{array}{c}\text { Basic Wood Density } \\
\left(\mathrm{g} \mathrm{cm}^{-3}\right)\end{array}$ & Carbon Content (\%) \\
\hline Casearia decandra Jacq. & 0.61 & 41.85 \\
\hline Casearia sylvestris Sw. & 0.56 & 42.92 \\
\hline Copaifera langsdorffii Desf. & 0.68 & 45.40 \\
\hline Cryptocarya aschersoniana Mez. & 0.58 & 43.44 \\
\hline Dalbergia nigra (Vell.) Allemão ex Benth. & 0.75 & 44.35 \\
\hline Guarea guidonia (L.) Sleumer & 0.65 & 42.14 \\
\hline Guazuma crinita Mart. & 0.48 & 43.77 \\
\hline Lithraea molleoides (Vell.) Engl. & 0.69 & 44.20 \\
\hline Machaerium villosum Vogel & 0.77 & 46.27 \\
\hline Myrcia venulosa DC. & 0.64 & 44.80 \\
\hline Nectandra lanceolata Nees & 0.38 & 42.51 \\
\hline Nectandra nitidula Nees & 0.39 & 45.10 \\
\hline Nectandra oppositifolia Nees & 0.53 & 46.57 \\
\hline Ormosia arborea (Vell.) Harms & 0.70 & 43.40 \\
\hline Peltophorum dubium (Spreng.) Taub. & 0.63 & 44.70 \\
\hline Persea willdenowii Kosterm. & 0.60 & 46.15 \\
\hline Protium heptaphyllum (Aubl.) Marchand & 0.52 & 43.39 \\
\hline Protium warmingianum Marchand & 0.53 & 42.89 \\
\hline Tapirira obtusa (Benth.) J.D.Mitch. & 0.47 & 43.66 \\
\hline Vismia brasiliensis Choisy & 0.64 & 45.04 \\
\hline Mean (Standard Deviation) & $0.59(0.11)$ & $44.13(1.37)$ \\
\hline Confidence interval & $0.59 \pm 0.05$ & $44.13 \pm 0.60$ \\
\hline
\end{tabular}


dioxide in a Seasonal Semideciduous Forest in Rio Doce Valley, Minas Gerais. In an advanced succession area, the authors found an IPA of $_{C} .19 \mathrm{t} \mathrm{ha}^{-1}$ year-1 over a period of five years. Souza et al. (2012b) obtained an IPA $_{C}$ of 0.77 t ha $^{-1}$ year $^{-1}$ (five-year period) in a seasonal semideciduous forest in advanced middle-stage succession in eastern Minas Gerais.

The variation in carbon increment values may be associated with the physiognomy in which the survey was carried out (Gaspar et al., 2016), since the composition of the tree community, disturbance history, successional stage, and climatic and edaphic conditions, influenced the carbon sequestration potential between different tropical forest areas (Ngo et al., 2013).

The determination of IPA $\mathrm{C}_{\mathrm{C}}$ in tropical forests is of utmost importance given the predictive capacity of this data. From the IPA ${ }_{C}$, it is possible to estimate how much carbon will be stored in the forest biomass during a given period. Therefore, the generation of reliable biomass and carbon stock estimates and for their increments in different natural forest physiognomies is of paramount importance. These estimates can increase the quality of the databases and enable the generation of biomass and carbon growth and yield estimates, in addition to allowing a comparison between different studies.

\section{CONCLUSIONS}

In the Seasonal Semideciduous Forest remnant, a biomass stock of $126.92 \pm 0.09 \mathrm{t} \mathrm{ha}^{-1}$ was estimated, corresponding to $55.91 \pm 0.05 \mathrm{t} \mathrm{ha}^{-1}$ of carbon and an IPAC of $3.07 \mathrm{t} \mathrm{ha}^{{ } 1}$ year $^{\bigotimes 1}$. These results indicate that the studied remnant positively contributed to forest carbon storage. This trend can be extended to forests with characteristics similar to those evaluated in the present study. Therefore, the information generated by this study supports the implementation of low carbon policies, since it makes it possible to predict the amount of carbon dioxide that could be emitted into the atmosphere by natural forests in cases of deforestation or fire.

\section{SUBMISSION STATUS}

Received: 8 dec., 2015

Accepted: 17 may, 2017

\section{CORRESPONDENCE TO}

\section{Helane França Silva}

Departamento de Engenharia Florestal, Universidade Federal do Piauí - UFPI, Campus Professora Cinobelina Elvas, Rodovia Municipal Bom Jesus-Viana, Km 01, Planalto Horizonte, CEP 64900-000, Bom Jesus, PI, Brasil e-mail: helane.engflo@gmail.com

\section{REFERENCES}

Almeida EM, Campelo JH Jr, Finger Z. Determinação do estoque de carbono em teca (Tectona grandis LF) em diferentes idades. Ciência Florestal 2010; 20(4): 559-568. http://dx.doi.org/10.5902/198050982414.

Amaro MA, Soares CPB, Souza AL, Leite HG, Silva GF. Estoque volumétrico, de biomassa e de carbono em uma Floresta Estacional Semidecidual em Viçosa, Minas Gerais. Revista Árvore 2013; 37(5): 849-857. http://dx.doi. org/10.1590/S0100-67622013000500007.

Antunes FZ. Caracterização climática do Estado de Minas Gerais. Informe Agropecuário 1986; 12(138): 9-13.

Baker TR, Phillips OL, Malhi Y, Almeida S, Arroyo L, Di Fiore A et al. Variation in wood density determines spatial patterns in Amazonian forest biomass. Global Change Biology 2004; 10(5): 545-562. http://dx.doi. org/10.1111/j.1365-2486.2004.00751.x.

Brasil. Ministério do Meio Ambiente - MMA. Levantamento da cobertura vegetal nativa do bioma Mata Atlântica [online]. Brasília: MMA; 2007. [cited 2014 Feb 10]. Available from: http://mapas.mma.gov.br/mapas/aplic/ probio/datadownload.htm

Brown S. Estimating biomass and biomass change of tropical forests: a primer. Roma: FAO Forestry; 1997. Paper 134.

Calixto JT Jr, Drumond MA. Estudo comparativo da estrutura fitossociológica de dois fragmentos de Caatinga em níveis diferentes de conservação. Pesquisa Florestal Brasileira 2014; 34(80): 345-355. http://dx.doi. org/10.4336/2014.pfb.34.80.670.

Carvalho LS, Cerqueira RM, Silva GV, Silva ERM. Estoque de carbono em um fragmento de Floresta Estacional Semidecídua no município de Ribeirão Grande, São Paulo. Ecologia e Meio Ambiente 2014; 28(2): 73-85.

Chave J, Andalo C, Brown S, Cairns MA, Chambers JQ, Eamus D et al. Tree allometry and improved estimation of carbon stocks and balance in tropical forests. Oecologia 2005; 145(1): 87-99. http://dx.doi.org/10.1007/s00442005-0100-x. PMid:15971085.

Conti G, Díaz S. Plant functional diversity and carbon storage: an empirical test in semi-arid forest ecosystem. 
Journal of Ecology 2013; 101(1): 18-28. http://dx.doi. org/10.1111/1365-2745.12012.

Espírito-Santo FDB, Oliveira-Filho AT, Machado ELM, Souza JS, Fontes MAL, Marques JJGSM. Variáveis ambientais e a distribuição de espécies arbóreas em um remanescente de floresta Estacional Semidecídua Montana no campus da Universidade Federal de Lavras, MG. Acta Botanica Brasílica 2002; 16(3): 331-356. http://dx.doi.org/10.1590/ S0102-33062002000300006.

Faria RAVB. Estoque de carbono e atributos florísticos e edáficos de ecossistemas florestais em processo de restauração [tese]. Lavras: Departamento de Ciências Florestais, Universidade Federal de Lavras; 2012.

Figueiredo LTM, Soares CPB, Sousa AL, Leite HG, Silva GF. Dinâmica do estoque de carbono em fuste de árvores de uma Floresta Estacional Semidecidual. Cerne 2015; 21(1): 161-167. http://dx.doi.org/10.1590/0104776020 1521011529.

Gaspar RO, Castro RVO, Peloso RVD, Souza FC, Martins SV. Análise fitossociológica e do estoque de carbono no estrato arbóreo de um fragmento de Floresta Estacional Semidecidual. Ciência Florestal 2014; 24(2): 313-324. http://dx.doi.org/10.5902/1980509814569.

Gaspar RO, Lustosa IM Jr, Rodrigues MI, Araújo JBCN, Lobão MS. Dendrocronologia na análise de crescimento em diâmetro, volume, biomassa e dióxido de carbono no Cerrado. Nativa 2016; 4(1): 48-52. http://dx.doi. org/10.14583/2318-7670.v04n01a10.

Gibbs HK, Brown S, Niles JO, Foley JA. Monitoring and estimating tropical forest carbon stocks: making REDD a reality. Environmental Research Letters 2007; 2(4): 1-13. http://dx.doi.org/10.1088/1748-9326/2/4/045023.

Henry M, Besnard A, Asante WA, Eshun J, Adu-Bredu $\mathrm{S}$, Valentini R et al. Wood density, phytomass variations within and among trees, and allometric equations in a tropical rainforest of Africa. Forest Ecology and Management 2010; 260(8): 1375-1388. http://dx.doi.org/10.1016/j. foreco.2010.07.040.

Houghton R. Aboveground forest biomass and the global carbon balance. Global Change Biology 2005; 11(6): 945958. http://dx.doi.org/10.1111/j.1365-2486.2005.00955.x.

Intergovernmental Panel on Climate Change - IPCC. Good practice guidance for land use, land-use change and forestry. Japan: IGES; 2003.

Latorraca JVF, Albuquerque CEC. Efeito do rápido crescimento sobre as propriedades da madeira. Floresta e Ambiente 2000; 7(1): 279-291.

Lima JPC, Leão JRA. Dinâmica de crescimento e distribuição diamétrica de fragmentos de florestas nativa e plantada na Amazônia sul ocidental. Floresta e Ambiente 2013; 20(1): 70-79. http://dx.doi.org/10.4322/floram.2012.065.

Lung M, Espira A. The influence of stand variables and human use on biomass and carbon stocks of a transitional
African forest: implications for forest carbon projects. Forest Ecology and Management 2015; 351: 36-46. http:// dx.doi.org/10.1016/j.foreco.2015.04.032.

Moro MF, Martins FR. Métodos de levantamento do componente arbóreo-arbustivo. In: Felfilli JM, Eisenlohr PV, Melo MMRF, Andrade LA, Meira JAA No, editors. Fitossociologia no Brasil: métodos e estudos de caso. Viçosa: Editora UFV; 2011.

Ngo KM, Turner BL, Muller-Landau HC, Davies SJ, Larjavaara M, Nik Hassan NF et al. Carbon stocks in primary and secondary tropical forests in Singapore. Forest Ecology and Management 2013; 296: 81-89. http:// dx.doi.org/10.1016/j.foreco.2013.02.004.

Nogueira EM, Yanai AM, Fonseca FOR, Fearnside PM. Carbon stock loss from deforestation through 2013 in Brazilian Amazonia. Global Change Biology 2015; 21(3): 1271-1292. http://dx.doi.org/10.1111/gcb.12798. PMid:25380507.

Oliveira AT Fo, Ratter JA. Padrões florísticos das matas ciliares da região dos cerrados e a evolução das paisagens do Brasil Central durante o Quaternário tardio. In: Rodrigues RR, Leitão HF Fo, editors. Matas ciliares: conservação e recuperação. São Paulo: EDUSP; 2000.

Paiva AO, Rezende AV, Pereira RS. Estoque de carbono em cerrado sensu stricto do Distrito Federal. Revista Árvore 2011; 35(3): 527-538. http://dx.doi.org/10.1590/ S0100-67622011000300015.

Parresol BR. Assessing tree and stand biomass: a review with examples and critical comparisons. Forest Science 1999; 45(4): 573-593.

Ribeiro SC, Jacovine LAG, Soares CPB, Martins SV, Souza AL, Nardelli AMB. Quantificação de biomassa e estimativa de estoque de carbono em uma floresta madura no município de Viçosa, Minas Gerais. Revista Árvore 2009; 33(5): 917-926. http://dx.doi.org/10.1590/ S0100-67622009000500014.

Scolforo JR, Mello JM, Oliveira AD, Pereira RM, Guedes ICL. Volumetria, peso de matéria seca e carbono para o domínio atlântico em Minas Gerais. In: Scolforo JR, Mello JM, Silva CPC, editors. Inventário florestal de Minas Gerais: floresta estacional semidecidual e ombrófila-florística, estrutura, similaridade, distribuição diamétrica e de altura, volumetria, tendências de crescimento e manejo florestal. Lavras: UFLA; 2008a.

Scolforo JR, Mello JM, Oliveira AD, Carvalho LMT, Acerbi FW Jr. Amostragem e caracterização dos fragmentos inventariados. In: Scolforo JR, Mello JM, Silva CPC, editors. Inventário florestal de Minas Gerais: floresta estacional semidecidual e ombrófila-florística, estrutura, similaridade, distribuição diamétrica e de altura, volumetria, tendências de crescimento e manejo florestal. Lavras: UFLA; 2008b.

Scolforo JR, Rufini AL, Mello JM, Trugilho PF, Oliveira $\mathrm{AD}$, Silva CPC. Equações para o peso de matéria seca das fisionomias, em Minas Gerais. In: Scolforo JR, Oliveira AD, 
Acerbi FW Jr, editors. Inventário florestal de Minas Gerais: equações de volume, peso de matéria seca e carbono para diferentes fisionomias da flora nativa. Lavras: UFLA; 2008c.

Scolforo JR, Rufini AL, Mello JM, Oliveira AD, Silva CPC. Equações para a quantidade de carbono das fisionomias, em Minas Gerais. In: Scolforo JR, Oliveira AD, Acerbi FW Jr, editors. Inventário florestal de Minas Gerais: equações de volume, peso de matéria seca e carbono para diferentes fisionomias da flora nativa. Lavras: UFLA; 2008d.

Scolforo JR, Oliveira AD, Mello JM, Silva CPC, Guedes ICL. Análise da estrutura fitossociológica dos fragmentos amostrados da floresta estacional semidecidual e da floresta ombrófila. In: Scolforo JR, Mello JM, Silva CPC, editors. Inventário florestal de Minas Gerais: floresta estacional semidecidual e ombrófila - florística, estrutura, similaridade, distribuição diamétrica e de altura, volumetria, tendências de crescimento e manejo florestal. Lavras: UFLA; 2008e.

Scolforo JRS, Thiersch CR. Biometria florestal: medição, volumetria e gravimetria. Lavras: UFLA/FAEPE; 2004.

Sharma T, Kurz WA, Stinson G, Pellatt MG, Li Q. LI Q. A 100-year conservation experiment: impacts on forest carbon stocks and fluxes. Forest Ecology and Management 2013; 310: 242-255. http://dx.doi.org/10.1016/j.foreco.2013.06.048.

Silva ACS, Caioni C, Veiga JB, Rondon RM No, Oliveira AS. Estoque de biomassa aérea, carbono e sequestro de dióxido de carbono em sistemas florestais na Amazônia Mato-grossense. Acta Iguazu 2014; 3(4): 22-35.

Silva KE, Souza CR, Azevedo CP, Rossi LMB. Dinâmica florestal, estoque de carbono e fitossociologia de uma floresta densa de terra-firme na Amazônia Central. Scientia Forestalis 2015; 43(105): 193-201.

Soares CPB, Oliveira MLR. Equações para estimar a quantidade de carbono na parte aérea de árvores de eucalipto em Viçosa, Minas Gerais. Revista Árvore 2002; 26(5): 533-539. http://dx.doi.org/10.1590/S010067622002000500002 .

Soares CPB, Paula F No, Souza AL. Dendrometria e inventário florestal. Viçosa: Ed. UFV; 2011.

Souza AL, Boina A, Soares CPB, Vital BR, Gaspar RO, Lana JM. Estoque e crescimento em volume, biomassa, carbono e dióxido de carbono em Floresta Estacional Semidecidual. Revista Árvore 2011; 35(6): 1277-1285. http://dx.doi.org/10.1590/S0100-67622011000700014.
Souza CR, Azevedo CP, Rossi LMB, Silva KE, Santos J, Higuchi N. Dinâmica florestal e estoque de carbono em floresta primária na região de Manaus/AM. Acta Amazonica 2012a; 42(4): 501-506. http://dx.doi.org/10.1590/S004459672012000400007 .

Souza AL, Boina A, Soares CPB, Vital BR, Gaspar RO, Lana JM. Estrutura fitossociológica, estoques de volume, biomassa, carbono e dióxido de carbono em Floresta Estacional Semidecidual. Revista Árvore 2012b; 36(1): 169179. http://dx.doi.org/10.1590/S0100-67622012000100018.

Souza PB, Souza AL, Meira JAA No. Estrutura diamétrica dos estratos e grupos ecológicos de uma área de Floresta Estacional Semidecidual, em Dionísio, MG. Revista Árvore 2012c; 36(1): 151-160. http://dx.doi.org/10.1590/S010067622012000100016 .

Souza JS, Espírito-Santo FDB, Fontes MAL, OliveiraFilho AT, Botezelli L. Análise das variações florísticas e estruturais da comunidade arbórea de um fragmento de floresta semidecídua às margens do Rio Capivari, Lavras, MG. Revista Árvore 2003; 27(2): 185-206. http://dx.doi. org/10.1590/S0100-67622003000200009.

Souza JT, Fiorentin LD. Quantificação da biomassa e do carbono em povoamento de Eucalyptus grandis W. Hill ex Maiden, em Santa Maria, RS. Unoesc \& Ciência - ACET 2013; 4(2): 253-262.

Torres CMME, Jacovine LAG, Soares CPB, Oliveira SN No, Santos RD, Castro F No. Quantificação de biomassa e estocagem de carbono em uma Floresta Estacional Semidecidual, no Parque Tecnológico de Viçosa, MG. Revista Árvore 2013; 37(4): 647-655. http://dx.doi. org/10.1590/S0100-67622013000400008.

Vilela EA, Oliveira-Filho AT, Carvalho DA, Guilherme FAG, Appolinário V. Caracterização estrutural de floresta ripária do Alto Rio Grande, em Madre de Deus de Minas, MG. Cerne 2000; 6(1): 41-54.

Watzlawick LF, Ebling AA, Rodrigues AL, Veres QJI, Lima AM. Variação nos teores de carbono orgânico em espécies arbóreas da Floresta Ombrófila Mista. Floresta e Ambiente 2011; 18(3): 248-258. http://dx.doi.org/10.4322/ floram.2011.045.

Williamson GB, Wiemann MC. Age-dependent radial increases in wood specific gravity of tropical pioneers in Costa Rica. Biotropica 2010; 42(5): 590-597. http://dx.doi. org/10.1111/j.1744-7429.2009.00618.x. 